\title{
Other Medications Administered During Surgery Prior to Tumor Tissue Removal
}

National Cancer Institute

\section{Source}

National Cancer Institute. Other Medications Administered During Surgery Prior to

Tumor Tissue Removal. NCI Thesaurus. Code C159292.

A header on the form for medications administered during surg ery prior to removal of the tumor tissue. 